\title{
Participatory Demonstration and Evaluation of Improved Variety of Tef in Selected Districts of West and Kellem Wollega Zones
}

\author{
Ayalew Sida \\ Oromia Agricultural Research Institute, Haro Sebu Agricultural Research Canter, Haro Sebu, Ethiopia
}

\section{Email address:}

ayalew.sida@yahoo.com

\section{To cite this article:}

Ayalew Sida. Participatory Demonstration and Evaluation of Improved Variety of Tef in Selected Districts of West and Kellem Wollega Zones. International Journal of Education, Culture and Society. Vol. 2, No. 5, 2017, pp. 143-146. doi: 10.11648/j.ijecs.20170205.11

Received: November 28, 2016; Accepted: February 9, 2017; Published: October 24, 2017

\begin{abstract}
The trial was carried out during 2013 and 2014 cropping seasons in Hawa Gelan and Dale Sedi districts on 14 farmers' field by selecting two peasant associations from each district based on their tef production potentials. Accordingly, Immo and Arere Gebi kebeles were selected from D/sedi district while Arere and Hawa Moi were from Hawa Gelan district. Three varieties (Quncho, Guduru and Ziquala) including local check were evaluated with the objective of selecting adaptable and best performing tef variety under farmers management. Analysis of variance was done across location and the combined analysis of the two districts was also undergone. In Dale Sedi district, the mean grain yields of Guduru and Quncho varieties were 10.43 and $8.39 \mathrm{qt} / \mathrm{ha}$ while the yield of Ziquala (6.70 qt/ha) was less than the local variety. Similarly in Hawa Gelan district the mean yields of Guduru (8.92qt/ha) and Quncho (7.76qt/ha) remained higher than the local check (6.56qt/ha). The yield of Ziquala (6.16qt/ha) was also less than the local. The combined analysis of variance revealed the mean values of grain yield ranged from Ziquala (6.44 qt/ha) to Guduru (9.68qt/ha). Quncho and the local gave 8.07 and $7.39 \mathrm{qt} / \mathrm{ha}$ respectively. Farmers' selection criteria were grain yield and seed color. Based on their selection criteria, farmers preferred Guduru for grain yield and Quncho for grain yield plus its very white seeded color. Since, both varieties were preferred by the target community they are recommended to be scaled up.
\end{abstract}

Keywords: Farmers' Evaluation, Grain Yield, Teff

\section{Introduction}

Ethiopia is the center of origin and diversity for tef. It is adapted to a wide range of environments and is presently cultivated under diverse agro climatic conditions. It is day length sensitive and flowers best during 12 hours of daylight. Tef performs well between 1700 and $2400 \mathrm{~m}$; however, it can grow from sea level up to 2800 meters above sea level. Apart from other many cereal crops, tef can grow in different physiological conditions. Tef is cultivated in high rainfall areas with long growing periods. It can also grow in low rainfall and drought prone areas characterized by protracted growing seasons and frequent terminal moisture stress.

Most of Ethiopian farmers motivated to cultivate tef because of its relative merits over other cereals in the use of both the grain and straw. It is primarily grown for human consumption of its grain which is used to prepare a favorite food of most Ethiopian people called Enjera. Whereas, it's straw is a valuable feed during the dry season when there is an acute shortage. It is highly preferred by cattle over the straw of other cereals and demands high prices in the markets. It also serves to reinforce mud and plaster the wall in local house construction [1].

Ethiopia's crop agriculture in general, and the cereals subsector in particular, face serious challenges. Despite the aforementioned importance and large coverage area of tef, its productivity is low due to different factors such as lack of high yielding cultivars, poor management practices, weed, water lodging, low moisture and low fertility conditions. The average national yield of tef is 15.60 quintal per hectare [2].

Kellem and West Wollega zones have a high amount of annual rainfall that can enable farmers to grow twice a year and double their produce. Farmers of these areas traditionally practice double cropping using local varieties of tef after 
maize harvest in late August [3]. These local varieties of tef in spite of having early maturing character, are very poor in yield, susceptible to lodging and have little biomass than recently released varieties.

Haro Sebu Agricultural Research Centre was carried out adaptation trial of different tef varieties and had selected three top varieties. However, the adaptation was not seen under farmers' condition. The top down approach to variety selection and seed production in Sub-Saharan African countries resulted in small adopters of varieties mostly not suited to their climatic conditions and socio-economic circumstances [4].

Participatory technology evaluation on farmers management condition may have many advantages, such as increased and stable crop productivity, faster release and adoption of varieties, better understanding farmers' criteria for variety selection, enhanced biodiversity, increased cost effectiveness, facilitated farmers learning and empowerment [5]. The two way feedback between farmers and researchers is indeed vital component of high yielder and disease and pest resistant varietal development process [6].

Objective of the project

The project was initiated to achieve the following objectives.

- To evaluate and select well performed tef variety/varieties for their localities.

- To enhance the skill and knowledge of farmers in tef production and management practices.

- To strengthen linkage among farmers, researchers, development agents and other stakeholders

\section{Methodology}

The trial was carried out during 2013/2014 and 2014/2015 cropping seasons in Hawa Gelan and Dale Sedi districts on 14 farmers' field by selecting two peasant associations from each district based their tef production potentials in collaboration with District Agricultural and Rural Development office. Before starting this demonstration trial on farmers' field, training were given to the farmers on important management practices and monitoring required for the trial.

Three improved varieties of tef namely, Quncho, Guduru, DZ-cr- 358 (Ziquala) and one local check were tested for their adaptability with full participation of farmers in the study areas. The spacing between plots and rows were $1.0 \mathrm{~m}$ and $20 \mathrm{~cm}$ respectively. Each experimental plot had $10 \mathrm{~m} \mathrm{x}$ $10 \mathrm{~m}$ with a gross area of $100 \mathrm{~m}^{2}$. Planting was done in row by drilling at seed rate of $15 \mathrm{~kg} \mathrm{ha}^{-1}$. DAP was applied at the rate of $130 \mathrm{~kg} / \mathrm{ha}$ at sowing. UREA was also applied at the rate of $80 \mathrm{~kg} /$ hectare. Half was applied at the time of planting while the remaining the second half was applied at the time of tillering. Twice hand weeding and other management practices were done as required. Data on plant height $(\mathrm{cm})$, number of tillering, panicle length $(\mathrm{cm})$, lodging $(\%)$ and grain yield on plant basis were collected and subject to statistical analysis using SAS statistical software (SAS 9.0). Farmers' assessment feedback on the technologies (compatibility, affordability, complexity, and applicability) also collected through interacting with farmers.

\section{Result and Discussions}

\subsection{Agronomic Performance of Tef}

The analysis of variance revealed that there is significant variation among observed agronomic traits of tested tef varieties Quncho, Guduru, Ziquala and the local check. As it is observed in the above table Guduru with a plant height of $105.83 \mathrm{~cm}$ is the tallest plant among the tested tef varieties followed by Quncho, local and Ziquala with the magnitude of $105.38,95.95$ and $92.46 \mathrm{~cm}$ respectively. The statistical result at $<5 \%(\mathrm{p}<0.0001)$ showed Guduru is significantly vary from Ziquala and the local; but it is almost the same (no significant difference) with Quncho.

Table 1. Combined mean yield and agronomic traits for tested tef varieties in Dale Sedi and Hawa Gelan districts.

\begin{tabular}{|c|c|c|c|c|c|}
\hline Varieties & Plant height (cm) & No of tillering & Panicle length & Lodging (\%) & Grain yield (qt/ha) \\
\hline Quncho & $105.38^{\mathrm{a}}$ & $4.00^{\mathrm{ab}}$ & $46.02^{\mathrm{a}}$ & $16.03^{a}$ & $8.04^{b}$ \\
\hline Guduru & $105.83^{\mathrm{a}}$ & $4.46^{\mathrm{a}}$ & $47.38^{\mathrm{a}}$ & $15.25^{\mathrm{ab}}$ & $9.68^{\mathrm{a}}$ \\
\hline Ziquala & $92.46^{\mathrm{b}}$ & $3.32^{\mathrm{b}}$ & $42.85^{\mathrm{b}}$ & $9.64^{b}$ & $6.44^{\mathrm{c}}$ \\
\hline Local & $95.95^{\mathrm{b}}$ & $3.34^{\mathrm{b}}$ & $44.91^{\mathrm{ab}}$ & $17.00^{\mathrm{a}}$ & $7.39^{\mathrm{b}}$ \\
\hline LSD & 8.09 & 0.91 & 2.53 & 5.86 & 0.2 \\
\hline $\mathrm{CV}$ & 10.58 & 13.42 & 7.29 & 52.88 & 13.7 \\
\hline
\end{tabular}

source: on farm demonstration data

In case of number tillering per plant, Guduru had highest (i.e. 4.46) whereas Ziquala had the smallest than other varieties (3.32). Similarly, there was significant difference between Guduru and Ziquala variety in terms of plant height and also between Guduru and Local check. But there is no significant different difference between Guduru and local. Panicle length ranges from 42.85 (Ziquala) to 47.38 (Guduru). The local variety had highest lodging percentage of $17 \%$.

Guduru variety had better yield than all tested varieties which gave 9.86 quintal per a hectare; Quncho, local and Ziquala indicates second, third and last with 8.04, 6.44 and 7.39 respectively.

In general Guduru performed better in yield and in all tested agronomic traits than all other tested varieties whereas Ziquala had low performance in most agronomic traits and yield in spite of having low lodging due to its short height in nature. Quncho was the second better performed variety next to Guduru. 
Table 2. Mean yield and agronomic traits of tested tef varieties in Dale Sedi district.

\begin{tabular}{|c|c|c|c|c|c|}
\hline Varieties & Plant height (cm) & No of tillering & Panicle length & Lodging (\%) & Grain yield (qt/ha)) \\
\hline Quncho & $116.12^{\mathrm{a}}$ & $3.14^{\mathrm{ab}}$ & $46.75^{\mathrm{ab}}$ & $14.21^{\mathrm{ab}}$ & $8.39^{\mathrm{ab}}$ \\
\hline Guduru & $118.01^{\mathrm{a}}$ & $3.76^{\mathrm{a}}$ & $47.91^{\mathrm{a}}$ & $13.28^{\mathrm{bc}}$ & $10.43^{\mathrm{a}}$ \\
\hline Ziquala & $104.00^{\mathrm{b}}$ & $2.74^{b}$ & $43.88^{b}$ & $9.28^{\mathrm{c}}$ & $6.70^{\mathrm{c}}$ \\
\hline Local & $107 . .71^{\mathrm{b}}$ & $3.08^{\mathrm{ab}}$ & $46.06^{\mathrm{ab}}$ & $17.85^{\mathrm{a}}$ & $8.16^{\mathrm{bc}}$ \\
\hline Lsd & 4.85 & 0.84 & 3.54 & 4.36 & 0.25 \\
\hline $\mathrm{Cv}$ & 3.87 & 14.48 & 6.82 & 28.47 & 7.46 \\
\hline
\end{tabular}

Source: On farm demonstration data

The result of the analysis in the table 2 revealed that there is significant variation among the varieties in all tested agronomic traits. Guduru had high plant height, more number of tillering, large panicle length and high grain yield than other varieties of tef in this district. The result is similar with the result obtained from combined analysis of these agronomic traits. Quncho, local and Ziquala occupies the next $2^{\text {nd }}, 3^{\text {rd }}$ and $4^{\text {th }}$ rank respectively. Local variety used by farmers was highly affected by lodging problem which resulted in low yield than Guduru and Quncho. However, it was better performed than Ziquala.

Table 3. Mean yield and agronomic traits of tef varieties in Hawa Gelan district.

\begin{tabular}{|c|c|c|c|c|c|}
\hline Varieties & Plant height (cm) & No of tillering & Panicle length & Lodging (\%) & Grain yield (qt/ha)) \\
\hline Quncho & $94.64^{a}$ & $4.85^{\mathrm{a}}$ & $45.30^{\mathrm{ab}}$ & $16.28^{\mathrm{ab}}$ & $7.76^{\mathrm{b}}$ \\
\hline Guduru & $93.66^{\mathrm{a}}$ & $5.17^{\mathrm{a}}$ & $46.86^{\mathrm{a}}$ & $16.14^{\mathrm{ab}}$ & $8.92^{\mathrm{a}}$ \\
\hline Ziquala & $80.81^{\mathrm{b}}$ & $3.91^{\mathrm{b}}$ & $41.78^{b}$ & $10.00^{\mathrm{b}}$ & $6.16^{\mathrm{c}}$ \\
\hline Local & $84.81^{\mathrm{b}}$ & $3.80^{\mathrm{b}}$ & $43.77^{\mathrm{ab}}$ & $18.78^{\mathrm{a}}$ & $6.56^{\mathrm{b}}$ \\
\hline Lsd & 5.48 & 0.93 & 3.85 & 6.78 & 0.19 \\
\hline $\mathrm{Cv}$ & 5.52 & 18.82 & 7.71 & 39.43 & 14.59 \\
\hline
\end{tabular}

Source: On farm demonstration data

The result of analysis again revealed significant difference among the varieties under these agronomic traits. For example, Quncho and Guduru had higher plant height, number of tillering, panicle length and grain yield than Ziquala and local.

Comparison of the performance of these varieties in Dale Sedi and Hawa Gelan districts shows higher yield in Dale Sedi than Hawa Gelan district. For example, Guduru gave $10.43 \mathrm{qt} / \mathrm{ha}$ in Dale Sedi but, it gave 8.92 quintal per hectare whereas Quncho, Ziquala and the local variety gave relatively higher mean yield of $8.39,6.70$ and 8.16 quintal per hectare in Dale Sedi as compared to the mean yield of 7.76, 6.16 and $6.56 \mathrm{qt} / \mathrm{ha}$ respectively that of Hawa Gelan district.

\subsection{Technology Demonstration and Evaluation Methods}

Two major approach was used to deliver the varieties with their full packages and to evaluate the field performance of the technology. This was done by giving training at different stages of the implementation period and by organizing field day during the maturity stages of the crop.

Training was given for farmers and experts on importance of tef in improving small holder farmers' livelihood and the recommended packages (rate of seed and fertilizer, recommended spacing and herbicide). The training covered a total of 80 farmers, 12 development agents and 4 subject matter specialists. Among the farmers trained 55 of them were male while 25 were female.

Mini-field day was organized at Arere kebeles of Hawa
Gelan district and Immo kebeles of Dale Sedi district. Farmers of Hawa Moi kebeles were invited and participated on mini-field day organized at Arere Kebele. Similarly, farmers of Arere Gabi kebeles were participated on minifield day organized at Immo kebeles of Dale Sedi district. During this mini-field day around 120 farmers including nonFRG farmers and 16 experts were participated to evaluate the varieties and select best varieties.

\subsection{Farmers Preference on the Varieties}

Farmers have a broad knowledge base on their environments, crops and cropping systems built up over many years and do experiments by their own and generate innovations, even though they lack control treatment for comparison and statistical tools to test the hypothesis [7].

Tef has a number of peculiar features which make it a preferred crop among farmers. Being the most preferred staple food in the country, demand for the product is ever increasing [8]. Farmers' selection criteria were grain yield and seed color. Based on their selection criteria in both districts (i.e. Dale Sedi and H/Gelan) farmers were preferred first Guduru among the tested tef varieties due to its high grain yields, seed color and resistant to major disease. Secondly, Quncho was preferred by the farmers due to it is very white seeded color and high market demand. Among the farmers' selection criteria set in two districts, seed color and high market demand coincide with the participatory varietal selection of teff by [9]. 
Table 4. Farmers' varietal selection criteria and the average scores given by the farmers.

\begin{tabular}{|c|c|c|c|c|}
\hline \multirow{2}{*}{ Criteria } & \multicolumn{4}{|l|}{ Varieties } \\
\hline & Guduru & Quncho & Ziquala & Local \\
\hline Seed Color & 4 & 5 & 3 & 2 \\
\hline Straw Biomass & 5 & 3.5 & 2 & 3 \\
\hline Market Demand & 5 & 5 & 3 & 3 \\
\hline Lodging Tolerance & 3 & 3 & 4 & 2.5 \\
\hline Grain Yield & 5 & 4 & 3 & 3.5 \\
\hline Total Score & 22 & 20.5 & 15 & 14 \\
\hline Average Score & 4.4 & 4.1 & 3 & 2.8 \\
\hline Rank & $1^{\text {st }}$ & $2^{\text {nd }}$ & $3^{\text {rd }}$ & $4^{\text {th }}$ \\
\hline
\end{tabular}

*scores ranges (2-5), 2 for minimum value and 5 for maximum value

\section{Conclusion}

Three varieties (Quncho, Guduru and Ziquala) including local check were evaluated with the objective of selecting adaptable and best performing tef variety with full participation of farmers. It was carried out on 14 farmers' field for 2013 and 2014 cropping season in Dale Sedi and Hawa Gelan districts. Different agronomic traits like plant height, number of tillering, panicle length, lodging and grain yield were considered by the researchers as evaluation criteria.

The analysis showed significant variation among the varieties tested in the trial. Guduru variety gave highest grain yield relative to the rest varieties in both districts followed by Quncho. On the contrary, Ziquala gave lower yield than the local check in both districts of the trail location.

The combined analysis of variance showed higher yield of Guduru which is 9.68 quintal per hectare whereas Quncho gave 8.07 quintals from a hectare. On the other hand, Ziquala gave low yield of 6.44 quintal per hectare while the local variety gave 8.16 quintal hectare which is greater than the yield of Ziquala.

Moreover, comparison of the yield performance of these varieties in Dale Sedi and Hawa Gelan districts showed higher yield in Dale Sedi than Hawa Gelan district. For example, Guduru gave $10.43 \mathrm{qt} / \mathrm{ha}$ in Dale Sedi but, it gave 8.92 quintal per hectare in Hawa Gelan. similarly, Quncho, Ziquala and the local variety gave relatively higher mean yield of $8.39,6.70$ and 8.16 quintal per hectare in Dale Sedi as relative to Hawa Gelan district which is 7.76, 6.16 and 6.56 quintal per hectare respectively.

Farmers' feedback assessment about the technologies compatibility and performance were assessed. Farmers' selection criteria were straw biomass, market demand, lodging tolerance, grain yield and seed color. Based on their selection criteria, farmers selected Guduru for grain yield and Quncho for yield plus its very white seeded color. Since, both varieties were preferred by the farmers, both are recommended to be scaled up.

\section{References}

[1] Engdawork Tadesse (2009). "Understanding Tef: A Review of Supply and Marketing Issues. Ethiopia Commodity Exchange Authority, Addis Ababa.
[2] Central Statistical Agency (CSA-2016). Agricultural Sample Survey 2013/2014 (2006 E. C.); Report On Area Production of Major Crops, Volume I, Statistical Bulletin, may 2016, Addis Ababa.

[3] Tadesse Birhanu, Bayisa Gedafa, Tesfaye Midheksa, Teshome Gutu, Demeksa Umer, TesfuBiru and Addisu Hailu (2011; unpublished). "Report on Characterization and Analysis of Farming System in Major Agro- ecologies of Kellem Wollega Zone. Oromia Agricultural Research Institute Bako Agricultural Research Center, Addis Ababa

[4] Foti, R. C.; M. Mapiye; M. Mutenje; M., Mwale and N. Mlambo, Farmer participatory screening of maize seed varieties for suitability in risk prone, resource-constrained smallholder farming systems of Zimbabwe; African Journal of Agricultural research Vol. 3 (3) 180-185, 2008

[5] Sperling L. E.; J. A. Ashby; M. E. Smith; E. Weltzen and S. McGuire, Participatory plant breeding approaches and results. Euphytica 122: 439-450, 2001.

[6] Getachew Belay, Hailu Tefera, Anteneh Getachew, Kebebew Assefa and Gizaw Metaferia (2008). Ethiopian Institute of Agricultural Research, Debre Zeit Centre, P. O. Box 32, Debre Zeit, Ethiopia. "Highly client-oriented breeding with farmer participation in the Ethiopian cereal tef [Eragrostis tef) ". African Journal of Agricultural Research Vol. 3 (1), pp. 022-028, January 2008.

[7] Bänziger, M.; G. O. Edmeades; D. Beck and M. Bellon, Breeding for drought and nitrogen stress tolerance in maize: From theory to practice. CIMMYT, Mexico, 2000, pp. 68.

[8] Engdawork Tadesse (2009), "Ethiopia Commodity Exchange Authority 'Understanding Teff': A Review Of Supply And Marketing Issues, Addis Ababa, Ethiopia.

[9] Belay, G., Tefera, H., Tadesse, B., Metaferia, G., Jarra, D. And Tadesse, T. (2006) 'Participatory Variety Selection In The Ethiopian Cereal Tef (Eragrostis Tef)', Experimental Agriculture, 42 (1), Pp. 91-101. Doi: $10.1017 / \mathrm{S} 0014479705003108$.

[10] Hailu T, Seyfu K (2001). Production and Importance of Tef in Ethiopian Agriculture. Proceeding of the "Inernational Workshop on Teff Genetics and Improvement" Debre Zeit, Ethiopia. 